\title{
Digital Based Literature Learning Enhancement: Vista Sastra
}

\author{
Mu'jizah $^{1}$, Winci Firdaus ${ }^{2}$, Suyono Suyatno ${ }^{3}$, dan Rohim ${ }^{4}$ \\ \{mujizah555@gmail.com¹, wincifirdaus1@gmail.com² \\ Balitbang dan Diklat Kementerian Agama, Indonesia ${ }^{1}$ \\ Badan Riset dan Inovasi Nasional, Indonesia ${ }^{234}$
}

\begin{abstract}
During the rapid development of information technology, the existence of a digital-based literature learning page was very much needed. This page can increase students' reading interest. On the literature page, students learn aesthetics, language enrichment, character education, imagination, and creation. For this reason, the Vista Sastra page was created as the final product of the feasibility study of students' literary reading material. This page was a digital-based literary learning enrichment. The goal was to find a way to increase interest in reading literature for high school students. Research and development method were used in this research. The steps taken include selecting literary reading, testing, selecting selected literature recommendations, creating page, and testing page. This literature learning platform was prepared to assist high school students in getting to know the richness of Indonesian literature, author's bio and creative process, guidelines, discussion forums, and evaluation. Vista Sastra can help students learn literature effectively and efficiently and independently build their imagination and creativity.
\end{abstract}

Keywords: character building, literary works, recommendations, imagination.

\section{Pengayaan Pembelajaran Sastra Berbasis Digital: Vista Sastra}

\begin{abstract}
Abstrak. Pada masa pesatnya perkembangan teknologi informasi, keberadaan laman pembelajaran sastra berbasis digital sangat diperlukan. Laman ini dapat meningkatkan minat membaca siswa. Dalam laman sastra, siswa belajar estetika, pengayaan bahasa, pendidikan karakter, berimajinasi, dan berkreasi. Untuk itu, dibuat laman Vista Sastra sebagai produk akhir penelitian kelayakan bahan bacaan sastra siswa. Laman ini adalah pengayaan pembelajaran sastra berbasis digital. Tujuannya untuk menemukan cara meningkatkan minat baca sastra bagi siswa SMA. Metode riset dan pengembangan digunakan dalam penelitian ini. Langkah-langkah yang dilakukan meliputi pemilihan bacaan sastra, uji coba, rekomendasi sastra terpilih, pembuatan laman, dan uji coba laman. Wadah pembelajaran sastra ini dipersiapkan untuk membantu siswa SMA dalam mengenal khazanah sastra Indonesia, biodata pengarang dan proses kreatifnya, panduan, forum diskusi, dan evalusi. Vista Sastra dapat membantu siswa dalam belajar sastra dengan efektif dan efisien serta merdeka membangun imajinasi dan kreativitas.
\end{abstract}

Kata kunci: digital, pembelajaran sastra, rekomendasi, Vista Sastra. 


\section{Pendahuluan}

Indonesia adalah sebuah bangsa yang multietnik, multibahasa, dan multibudaya dengan persebaran wilayah yang luas. Kekayaan itu merupakan keberkahan sekaligus kendala dalam pengelolaannya. Salah satu kendala tersebut adalah dalam bidang pendidikan. Hingga saat ini masih dikeluhkan rendahnya minat baca siswa. Berdasarkan hasil PISA (Programme for International Student Assessment) tahun 2018, Indonesia menduduki posisi keenam untuk sistem pendidikan membaca dan matematika serta posisi kesembilan untuk pendidikan sains. Keluhan lainnya adalah pelajaran sastra masih menjadi bagian pelajaran bahasa Indonesia. Keluhan juga datang dalam sistem pembelajaran yang terkungkung kurikulum, bahan ajar, dan RPP. Meskipun saat ini telah dirancang belajar merdeka, kesiapan prasarana dan sarana masih belum matang.

Rendahnya minat baca dalam pendidikan ini menjadi sebuah ironi sebab Indonesia memiliki kekayaan sastra yang berlimpah dan sudah mendunia. Sejak abad ke-19 karya sastra klasik Indonesia sudah menjadi bahan kajian peneliti Eropa [1]. Karya sastra klasik Indonesia yang berbentuk manuskrip disimpan di 30-an negara di dunia [2]. Kekayaan sastra itu mempunyai masa rentang yang panjang. Suku Jawa pada abad ke-10 sudah mengenal Arjuna Wiwaha. Suku Melayu abad ke-14 sudah mengenal Kitab Tanjung Tanah [3]. Suku-suku lain di Indonesia juga banyak yang literasinya sudah maju sejak zaman dahulu, seperti Minangkabau, Aceh, Palembang, Bugis, Makassar, Buton, Bima, dan Ternate. Bahkan, empat sastra klasik Indonesia telah diakui UNESCO sebagai warisan dunia berasal dari Indonesia, yakni Negarakertagama, Babad Diponegoro, I La Galigo, dan Cerita Panji. Kini beberapa sastrawan kenamaan Indonesia, seperti Pramoedya Ananta Toer, Goenawan Mohamad, Sapardi Djoko Damono, dan Ayu Utami juga sudah mendunia. Karya-karya mereka telah diterjemahkan ke dalam berbagai bahasa dunia.

Karya sastra adalah karya penting dan menjadi identitas kebangsaan. Sastra adalah cermin peradaban suatu bangsa [4]. Karya yang indah ini berisi pemikiran yang diungkapkan dengan gaya yang khas. Sastra juga merupakan dokumen sosial yang merekam berbagai peristiwa dalam masyarakat, mulai dari mitos sampai sejarah. Sastra mengajarkan sesuatu dengan cara yang indah atau estetis. Dengan peran seperti itu, sastra harus hadir dalam kehidupan siswa dan apresiasi sastra sangat perlu diajarkan kepada siswa.

Generasi muda saat ini tumbuh di lingkungan teknologi informasi yang berkembang pesat. Pergeseran dunia cetak ke dunia digital ini dapat dimanfaatkan untuk menjembatani remaja yang belum begitu familiar dengan sastra. Masalahnya dari banyaknya karya sastra yang ada di Indonesia, karya sastra mana yang akan diberikan dalam pembelajaran atau pengayaan sastra dan bagaimana cara efektif serta efisien dalam memanfaatkan sistem informasi untuk pembelajaran sastra? Tujuan penelitian ini menemukan karya sastra yang layak sebagai bahan pembelajaran sastra dan menyediakan pembelajaran sastra berbasis digital agar siswa SMA dapat memahami dan mengapresiasi karya sastra dengan baik [5].

Untuk menjawab masalah tersebut, [6] dilakukan penelitian Kelayakan Bahan Bacaan Sastra untuk Siswa SMA. Dari hasil penelitian, telah direkomendasi 45 karya sastra untuk siswa SMA. Karya-karya sastra yang dianggap layak dan berterima oleh siswa SMA ini ditindaklanjuti dengan pengembangannya berupa rancangan produk pembelajaran sastra berbasis digital. Sistem pembelajaran untuk memperkaya bahan ajar dan membantu dalam pembelajaran sastra.

Pada dasarnya penelitian pembelajaran sudah pernah dilakukan, di antaranya penelitian berbasis teks [7]. Di samping itu ada juga penelitian yang berkaitan dengan digital. Namun penelitiannya masih berada pada tataran teoretis. [8] Rahmadi, Muhammad (tanpa Tahun) 
mengatakan ada lima faktor dalam strategi dan inovasi dalam pembelajaran bahasa dan sastra Indonesia yang harus dikuasai dosen dan mahasiswa, yaitu kritis, kreatif, komunikatif, kolaboratif, menguasai teknologi informasi, dan kaya strategi inovatif serta berkarakter. [9] Sarwiji (2018) meneliti "Tantangan Mewujudkan Pembelajaran Bahasa dan Sastra Indonesia yang efektif di era revolusi industri 4.0". Penelitian lainnya oleh Firmansyah (tanpa tahun) yang menyatakan prinsip pembelajaran sastra digital. Hasil penelitian tersebut menunjukkan bahwa prinsip pembelajaran sastra digital mencakup tradisi, tekstualitas, dan metodologis. Sehubungan dengan hal itu, dalam penelitian kelayakan ini diciptakan sebuah pengayaan pembelajaran sastra yang berbasis digital.

\section{Metode}

Penelitian Kelayakan Bahan Bacaan Sastra untuk Siswa SMA yang sudah dilakukan menggunakan pendekatan R \& D (research and development) serta telah menghasilkan sebuah produk. Penciptaan produk tersebut menggunakan pendekatan kualitatif dan kuantitatif. Pendekatan kuantitatif dilakukan pada tahap pemilihan karya sastra sedangkan pendekatan kuantitatif dilakukan pada tahap uji coba di lapangan, evaluasi dan revisi [11].

Menurut Gall dan Borg dalam Emzir (2018), penelitian dan pengembangan awalnya digunakan pada bidang teknologi dan industri untuk menemukan inovasi yang bersifat timbal balik. Penelitian ini menghasilkan sebuah produk baru atau menyempurnakannya dengan ilmiah. Model penelitian ini meliputi studi pendahuluan berupa penelitian dan pengumpulan data, pengukuran kebutuhan, dan studi pustaka. Perencanaan penelitian berupa penyusunan rencana penelitian yang meliputi kemampuan yang diperlukan dalam pelaksanaan penelitian, rumusan tujuan dalam penelitian, desain atau langkah-langkah penelitian, dan kemungkinan pengujian dalam lingkup terbatas.

Tahap berikutnya adalah pengembangan produk awal, berupa pengembangan bahan pembelajaran, proses pembelajaran, dan evaluasi instrumen. Kemudian tahap uji coba lapangan awal secara terbatas, revisi hasil uji lapangan terbatas, uji lapangan lebih luas, revisi hasil uji lapangan, uji kelayakan, revisi hasil uji kelayakan, dan diseminasi serta sosialisasi produk akhir.

\section{Hasil dan Pembahasan}

\subsection{Rekomendasi Karya Sastra}

Seperti sudah dinyatakan, untuk pemilihan bahan bacaan sastra telah direkomendasi 45 karya sastra dari hasil penelitian yang dilakukan tahun 2017--2019 [13]. Karya sastra tersebut terdiri atas 15 karya sastra klasik dan 30 sastra modern. Sastra klasik itu berasal dari pantun, hikayat, dan syair, seperti Hikayat Merpati Mas dan Merpati Perak, Syair Siti Zubaedah, Babad Diponegoro, dan Hikayat Pandji Semirang. Sastra modern berasal dari genre puisi, cerpen, drama, dan novel. Penelitian pada tahun 2019 adalah pengembangan bahan yang diambil dari sepuluh karya sastra modern. Karya sastra itu adalah "Anjing-anjing Menyerbu Kuburan", "Guru", “Indonesia Tanah Sajadah", "Manusia Pertama di Angkasa Luar", "Lampu Kristal”, "Tarian Bumi”, "Bunga Rumah Makan”, "Pada Suatu Hari”, "Ibu yang Tabah”, dan 
"Lagu Gadis Itali". Karya sastra yang direkomendasi tersebut akan ditindaklanjuti dalam model pembelajaran sastra berbasis digital.

Untuk mengetahui kelayakan dan keberterimaannya karya-karya sastra terpilih diujicobakan kepada siswa di beberapa sekolah SMA dengan masing-masing sekolah 20 siswa. Pengolahan hasil uji coba digunakan dengan Skala Likert. Skala tersebut mempunyai gradasi dari sangat positif sampai sangat negatif. Sistem penilaian dalam skala Likert adalah (1) sangat setuju, (2) setuju, (3) tidak setuju, dan (4) sangat tidak setuju. Indikator layak dan berterima dilihat dari pengetahuan, nilai, pemahaman, sikap, dan minat serta kemampuan siswa terhadap karya sastra yang diujicobakan.

Uji coba dari kuesioner yang berisi sampel karya sastra tersebut dilakukan di wilayah barat, yaitu Aceh dan Sumatra Utara, wilayah tengah yaitu di Yogyakarta, dan wilayah timur di NTT. Wilayah-wilayah tersebut dipilih dengan pertimbangan keberadaan wilayah. Sekolah yang dipilih untuk uji coba adalah sekolah dengan nilai UAN tinggi, menengah, dan rendah.

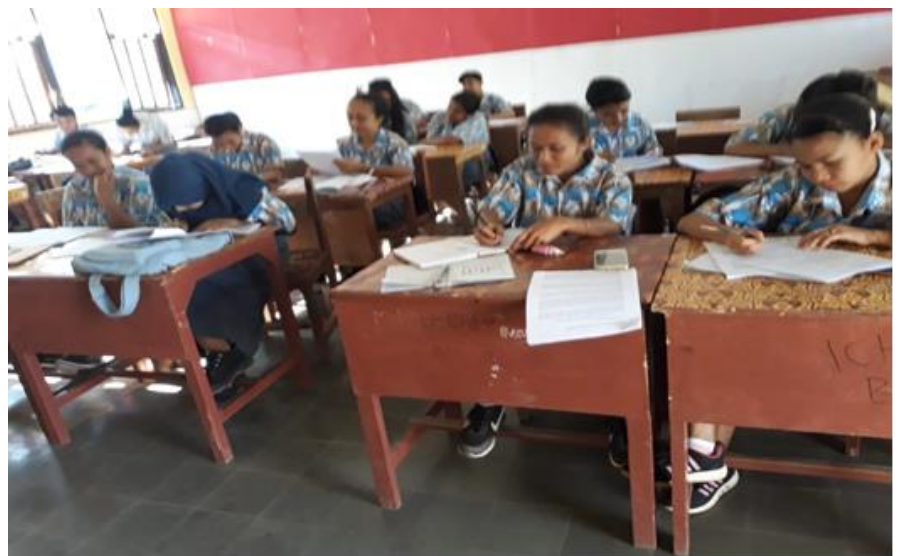

Gambar 1. Suasana Uji Coba Karya Sastra di SMA 3 Kota Kupang, Yogyakarta

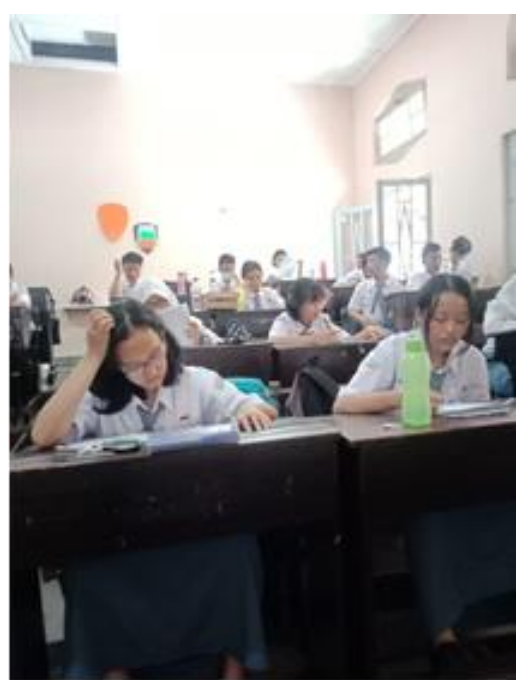

Gambar 2. Suasana Uji Coba Karya Sastra di SMAN 1, Yogyakarta 
Dari hasil uji coba tersebut dilakukan pengolahan data. Salah satu hasil pengolahan data yang diujicobakan di SMA di Yogyakarta dapat diketahui dalam grafik. Grafik tersebut memperlihatkan kelayakan atau keberterimaan sepuluh karya sastra dengan perolehan nilai rata-rata sebagai berikut:

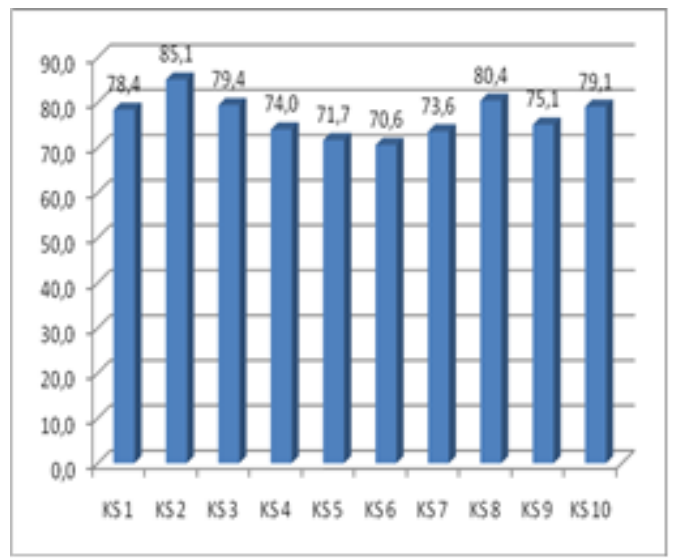

Gambar 3. Nilai Kelayakan atau Keberterimaan Sepuluh Karya Sastra

Dari grafik tersebut dapat diketahui bahwa nilai tertinggi diperoleh karya sastra (KS 2) yang berjudul "Guru" dengan nilai tertinggi 85,1 dan nilai terendah diperoleh karya sastra (KS 6) yang berjudul "Manusia Pertama di Angkasa" dengan nilai 70,6. KS 1 yang berjudul "Anjing-anjing Menyerbu Kuburan" memperoleh nilai 78,4, KS 3 yang berjudul "Indonesia Tanah Sajadah" memperoleh nilai 79,4. Kemudian, KS 4 yang berjudul "Lampu Kristal" memperoleh nilai 74,0. Karya sastra (KS 5) yang berjudul "Tarian Bumi" memperoleh nilai 71,7, KS 7 yang berjudul "Bunga Rumah Makan" memperoleh nilai 73,6, KS 8 yang berjudul "Pada Suatu Hari" memperoleh nilai kedua tertinggi, yakni 80,4, dan karya sastra (KS 9) yang berjudul "Ibu yang Tabah" memperoleh nilai 75,1 serta KS 10 yang berjudul "Lagu Gadis Itali” memperoleh nilai 79,1.

Dari perolehan nilai tersebut terlihat bahwa kesepuluh karya yang diujicobakan layak atau berterima karena nilainya memenuhi standar kelayakan, rata-rata di atas 70 . Hal itu berarti bahwa sepuluh karya sastra yang direkomendasi memenuhi syarat untuk ditindaklanjuti sebagai bahan pengembangan untuk pengayaan pembelajaran bahan sastra. Karya-karya terpilih yang sudah diujicobakan akan dijadikan sebagai bahan dalam pengembangan penelitian berupa rancangan laman pembelajaran sastra berbasis digital.

\subsection{Pengayaan Bahan Pembelajaran Sastra Berbasis Digital}

Dari hasil uji coba dan rekomendasi karya sastra, penelitian ditindaklanjuti dengan pembuatan produk pembelajaran sastra berbasis digital yang bernama Vista Sastra. Laman yang menjadi model produk lanjutan penelitian Kelayakan Bahan Bacaan Sastra siswa SMA ini berkonsep belajar sastra dengan serius, santai, dan merdeka.

Vista maknanya bentang alam, panorama, rekreasi, dan perspektivisme yang dalam hal ini berkaitan dengan sastra. Dalam laman ini, siswa khususnya SMA atau remaja serta peminat sastra mendapat wawasan berbagai hal yang berkaitan dengan karya sastra. Tujuannya adalah untuk meningkatkan kemampuan dalam mengapresiasi karya sastra. Khazanah sastra yang dimasukkan dalam Vista Sastra adalah sastra klasik dengan aneka genrenya dan sastra modern. Sastra klasik yang ditampilkan adalah karya sastra beraksara Latin dan cetakan. 
Dalam Laman Vista Sastra disajikan 8 rubrik (ruang), yakni (1) Beranda, (2) Khazanah/Koleksi Sastra (berisi beraneka karya sastra dari berbagai genre), (3) Siber Sastra, (4) Biografi Pengarang, (5) Panduan, (6) Ruang Bimbingan, (7) Forum Diskusi, (8) Ruang Evaluasi. Ruang khazanah sastra dalam pengembangannya dapat terus bertambah sesuai dengan perkembangan sastra. Namun, penambahannya harus melalui penelitian. Dalam pembuatan model ini misalnya dimasukkan 10 karya sastra yang direkomendasi (sesuai hasil penelitian Kelayakan Bahan Bacaan Sastra untuk Siswa).

Siber sastra atau ruang multimedia menyajikan berbagai karya sastra yang sudah dialihwahanakan dalam bentuk audio dan audiovisual. Karya itu berupa musikalisasi puisi, pembacaan karya sastra, film, komik, lukisan, teater, dan lainnya. Ruang panduan berisi buku cetakan atau artikel dan rekaman aoudiovisual berupa panduan yang mengarahkan cara mengapresiasi karya sastra. Ruang ini sejalan dengan ruang khazanah/koleksi. Rubrik ini dipandu oleh operator dan sastrawan.

Biografi dan proses kreatif sastrawan menyajikan riwayat hidup para sastrawan dan bagaimana cara sastrawan menciptakan karya sastranya. Dari rubrik ini pengunjung laman dapat belajar berproses kreatif dengan model sastrawan berkarya. Rubrik ini bisa diisi dengan artikel dan rekaman audiovisual seperti edisi film sastra yang dibuat oleh Yayasan Lontar. Ruang bimbingan (tutorial) adalah ruang yang mengakomodasi keinginan pengunjung yang ingin berkreasi dalam sastra. Ruang ini diasuh oleh sastrawan yang akan memberi petunjuk dan mengarahkan siswa, guru, serta peminat sastra apabila ingin menciptakan karya sastra.

Forum diskusi adalah ruang yang mengakomodasi para pengunjung dapat mendiskusikan berbagai hal yang berkaitan dengan sastra. Ruang ini dipandu oleh seorang operator, pakar sastra atau sastrawan. Ruang evaluasi adalah ruang penilaian yang dimanfaatkan pengelola laman Vista Sastra memperbaiki diri. Evaluasi ini berkaitan dengan dua hal, yakni (a) memperbaiki laman dan (b) mengembangkan karya sastra yang akan dimanfaatkan untuk penambahan koleksi. Kedua evaluasi ini dikreasi dalam bentuk kuesioner yang diisi oleh pengunjung. Evaluasi ini juga dapat digunakan sebagai bahan pengembangan untuk Penelitian Kelayakan Bahan Bacaan Sastra Siswa SMA.

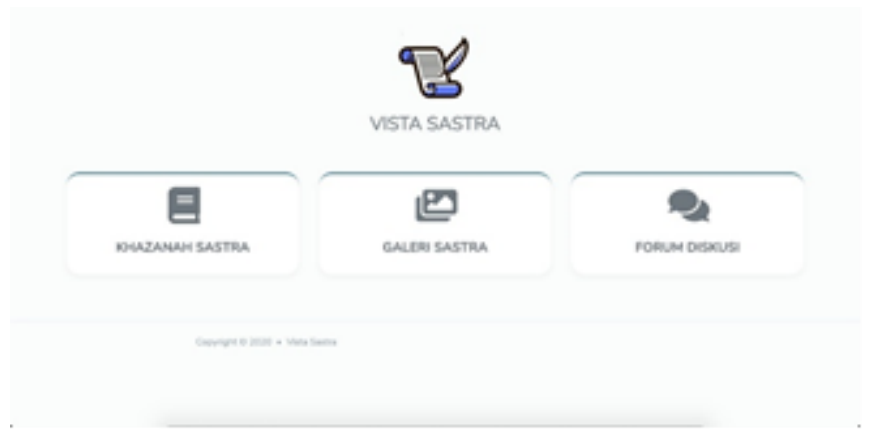

Gambar 4. Tampilan antarmuka Vista Sastra di laman 


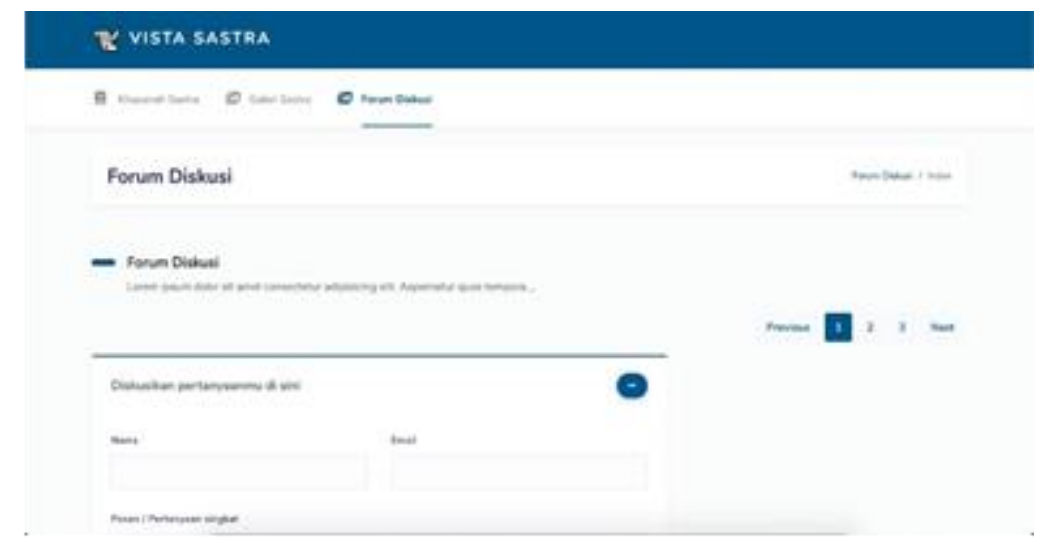

Gambar 5. Tampilan menu Forum Diskusi di Vista Sastra

Laman sastra yang dirancang sebagai pengembangan penelitian, rancangan sederhananya dapat dilihat dalam Laman Vista Sastra. Laman Vista Sastra saat ini masih dalam tahap perancangan dan terdapat di local host, dibutuhkan dukungan Badan Pengembangan dan Pembinaan Bahasa untuk memperbaiki hosting agar laman Vista Sastra dapat segera dinikmati oleh siswa, guru, dan pencinta sastra. Perlu dibuat tim khusus baik IT maupun pengisi konten pada laman Vista Sastra.

\section{Simpulan}

Pembelajaran sastra berbasis digital sudah sangat diperlukan saat ini. Perkembangan teknologi perlu dimanfaatkan secara maksimal. Dengan pembelajaran sastra berbasis digital, keterbatasan ruang dan waktu dapat diatasi. Laman digital pembelajaran sastra yang dinamakan Vista Sastra ini merupakan produk dari penelitian Kelayakan Bahan Bacaan Sastra untuk Siswa SMA. Sebagai sebuah penelitian, proses pembuatan laman ini membutuhkan waktu yang panjang, melalui penelitian pemilihan bahan bacaan sastra, uji coba, rekomendasi karya sastra, dan pembuatan Vista Sastra.

Dalam pemilihan bahan dilibatkan pakar sastra dan sastrawan untuk validasi ahli. Dari hasil penelitian ini direkomendasi 45 karya sastra yang dipilih. Karya sastra tersebut telah diujicobakan kepada siswa SMA. Karya sastra tersebut direkomendasi dan ditindaklanjuti dengan pembuatan laman Vista Sastra sebagai pembelajaran sastra berbasis digital. Laman yang masih dalam perancangan ini diharapkan menjadi sebuah produk pembelajaran sastra yang efektif dan efisien. Sebagai sebuah produk penelitian, nantinya laman ini akan diuji coba kepada siswa dan dievaluasi.

Dalam laman ini, siswa dan peminat sastra dapat membaca sastra, mengapresiasi, dan membuat sastra karena terdapat panduan serta bimbingan dari sastrawan. Mereka juga dapat berdiskusi dalam ruang forum diskusi. Laman dan bahan terus dikembangkan sesuai dengan perkembangan zaman karena dalam laman ini disediakan ruang evaluasi. 


\section{Referensi}

[1] Baried SB. Pengantar teori filologi. Yogyakarya: Universitas Gadjah Mada Press, 1994.

[2] Chambert-Loir H, Fathurrahman O.Panduan koleksi naskah-naskah Indonesia sedunia. Jakarta: Yayasan Obor Indonesia, 1999.

[3] Kozok U. Kitab Tanjung Tanah. Jakarta: Yayasan Obor Indonesia, 2006.

[4] Hartoko D, Rahmanto B. Pemandu di dunia sastra. Yogyakarta: Kanisius, 1986.

[5] Belang M, Gunawan T, Nurdiyati. Acuan pelajaran bahasa Indonesia 1B: Untuk kelas 1 Semester 2 SMP. Klaten: Intan Pariwara, 1990.

[6] Mu'jizah, Suyono S. Penelitian kelayakan bahan bacaan sastra untuk SMA di Yogyakarta dan NTT. Jakarta: Badan Pengembangan dan Pembinaan Bahasa, 2019.

[7] Taum YY. Pembelajaran sastra berbasis teks: Peluang dan tantangan kurikulum 2013. Sintesis. 2017; 11(1): 12-22

[8] Rahmandi M. Setrategi dan Inovasi dalam Pembelajaran Bahasa dan Sastra Indonesia di Era Industri 4.0. Pertemuan Ilmiah Bahasa dan Sastra Indonesia (PIBSI). 27-40

[9] Sarwiji S. Tantangan mewujudkan pembelajaran bahasa dan sastra Indonesia yang efektif di era revolusi industri 4.0. Makalah dipresentasikan dalam Kongres Bahasa Indonesia XI yang diselenggarakan Badan Pengembangan dan Pembinaan Bahasa Kementerian Pendidikan dan Kebudayaan, Jakarta. 28-31

[10] Firmansyah MB. Konseptualisasi pembelajaran sastra digital. Jurnal Ilmiah Edukasi \& Sosial. 2018; 9(1): 21-27

[11] Likert R. A Technique for the Measurement of Attitudes. Archives of Psychology. 1932; 140: 155

[12] Emzir. Metodologi penelitian pendidikan kuantitatif dan kualitatif. Jakarta: Rajawali, 2018.

[13] Mu'jizah. Kelayakan sastra melayu klasik sebagai bahan bacaan sastra siswa SMA: Sebuah evaluasi. Prosiding Seminar Nasional Bahasa dan Sastra: untuk Memperkuat Jatidiri Bangsa. 2019. 